\title{
Amino acid (Lysine) requirement of the Pig: Methods of Approach and Recommendations
}

\author{
W. WIESEMMÜLLER \\ Wilhelm-Pieck. Universität Rostock - Sektion Tierproduktion. Justus l'on Liebig Weg \\ DDR 25, ROSTOCK
}

\section{Summary}

Selection for leaner types of pigs is associated with a more sustained daily lean tissue growth and consequently with an increase in the daily lysine requirement. Accordingly, the lysine/ energy ratio should be constant for the whole fattening period between 35 and I $20 \mathrm{~kg}$ live weight.

Similar final carcass characteristics, i.e. the same amount of deposited protein, at a given slaughter weight, may be obtained by distinct energy levels and lysine/energy ratios. For the limiting amino acid (lysine) the lysine /energy ratio was $2.0 \mathrm{~g} / \mathrm{Mcal} \mathrm{D}$.E. and, taking into account amino acid digestibility, I.8 g dig. lysine/Mcal D.E.

To optimize energy and protein (lysine) allowances for a given slaughter weight the energy level and profile should be adjusted to the final fattening weight. This is of great importance for producing heavy pigs as compared to lighter ones.

Very high energy consumption in the fattening stage of 35 to $70 \mathrm{~kg}$ resulted in a decline of weight and protein deposition at the end of the fattening period from about $90 \mathrm{~kg}$ live weight onwards. It cannot be compensated for by a high protein supplementation. At a finishing weight of $120 \mathrm{~kg}$ a too intensive nutrient level (more than $650 \mathrm{~g}$ gain/day) at the first fattening stage proved to be unfavourable. The resulting depression of protein deposition in the second fattening period accounts for an insufficient expression of the muscle growth potential. It is defined as the upper limit of protein deposition (and consequently lean meat production) in a fattening animal at a given final weight for minimizing both the fattening length and fat deposition. When producing heavy pigs, a reduction of energy supply during the second half of the fattening period is not advisable when using modern crossbred lean pigs. On the contrary, all efforts should be made so that the energy intake during the second half of the fattening period is not limiting for lean tissue growth.

\section{Introduction}

The amino acid requirement depends upon performance and age. The effect of protein feeding in fattening pigs was first studied in our laboratory by means of nitrogen balance experiments. Various amounts of different protein sources were added together to a protein-free basal diet (WIESEMÜLIER and POPPE, I969). The nitrogen balance measurements showed that a smaller quantity of egg protein is required to obtain a given nitrogen balance than from barley or sesame protein. In other words, a given performance is obtained with a considerably lower protein 
level if a high-quality protein is used instead of a low quality protein. Thus, for the dietary protein content, considerable differences are observed in growth performance when proteins of different qualities are used. Therefore, formulation of pig diets should not be based only on total protein. In each case the reasons for the differences on performance and nitrogen balance can be explained by the corresponding intakes of the limiting amino acid, 1ysine for instance. In this connection it does not matter whether the diet involved contains vegetable protein or high value protein of animal origin (POPPE and WIESEMÜLLER, I968).

The recommended allowances of amino acids were calculated on the basis of the minimum intake required to obtain a nitrogen balance which did not differ statistically from the maximum nitrogen balance as determined mathematically with a curvilinear function. These requirement values were determined within short intervals during the whole fattening period.

In the meantime, the values obtained from nitrogen balance experiments were checked during both fattening and slaughtering experiments using "Edelschwein" and "Landrace " crossbreds (WIESEMÜLLER, POPPE and SIEG, I974; JANCKER and POPPE, I 975). Recently we also studied to which extent breeding progress and changes in genetic potential may modify the nutritional requirements. Investigations were made to test the variation in the lysine requirement of the growing pig according to the dietary energy level and lean growth potential. The results obtained on animals from the rotational breeding programme have been published (WIESEMÜLLER et al., I978) and will be discussed here together with results obtained on crossbred pigs.

\section{Materials and Methods}

In order to allow a rapid introduction of our research results into the feed industry, these studies were devoted to lysine, the limiting amino acid, all other essential amino acids being present in the experimental rations at such concentrations that requirements could be met.

One hundred and fifteen crossbred castrated males (Flelschwein $\times$ Landrace) $\times \mathrm{K} 25^{\circ}$ and $\mathrm{O}_{5}$ crossbred gilts (Fdelschwein $\times$ Landrace) $\times$ F I 50 were fattened from 35 to $\mathrm{I} 20 \mathrm{~kg}$ live weight. In addition, in the second group of pigs 35 castrated males were fattened for comparison. All pigs were kept in individual pens.

The line $\mathrm{K} 25^{\circ}$ was bred for rotation crossing in order to improve the fertility performance of the "hybrid" sows. This line is based on the Estonian Bacon Race, the Lithuanian Large White, the Sattel Swine, the Landrace line 05 and the Duroc. The line designated F I5o with rapid meat gain rates has been created for cross-breeding. The breeds originally used, in a variety of combinations, for the crossing scheme were the Pietrain, Lacombe, Belgian Landrace and Hampshire.

Some of the pigs were slaughtered at 40,70 , and $95 \mathrm{~kg}$ liveweight and analysis of the chemical composition was performed.

The experiment was designed to test the effects of lysine intake at 8o, Ioo, and $\mathrm{I} 20 \mathrm{p}$. roo of the recommended level at a mean energy intake estimated to be adequate for a daily gain of around $600 \mathrm{~g}$ during the whole fattening period. In addition, a lower level of energy intake with amounts of lysine representing 80 and roo p. Ioo of the recommended level, and a high energy level during the fattening period, were tested. Table I gives some precisions about the energy and lysine levels used. 
TABLE I

Variation in daily energy and lysine supply according to live weight

\begin{tabular}{|c|c|c|c|c|c|}
\hline Level & $4^{\circ}$ & 60 & 80 & I 00 & $\begin{array}{c}\text { I } 20 \mathrm{~kg} \\
\text { live weight }\end{array}$ \\
\hline
\end{tabular}

Trial I : Castrated males (Edelschwein $\times$ Landrace) $\times \mathbf{K} 25^{\circ}$

Energy intake: Mcal D.E. per day

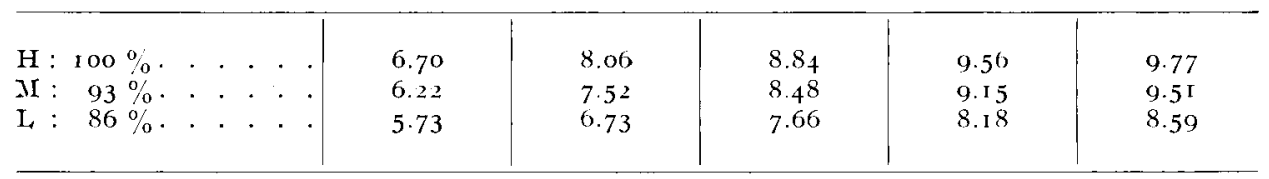

Lysine intake: g per day

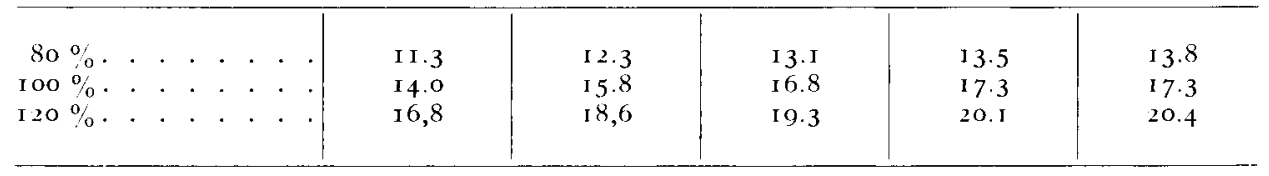

Trial 2: Fattening gilts (Edelschwein $\times$ Landrace) $\times$ F $5_{50}$

Energy intake: Mical D.E. per day

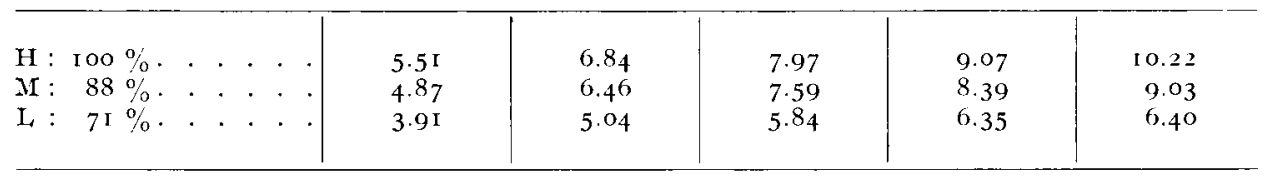

Lysine intake: $g$ per day

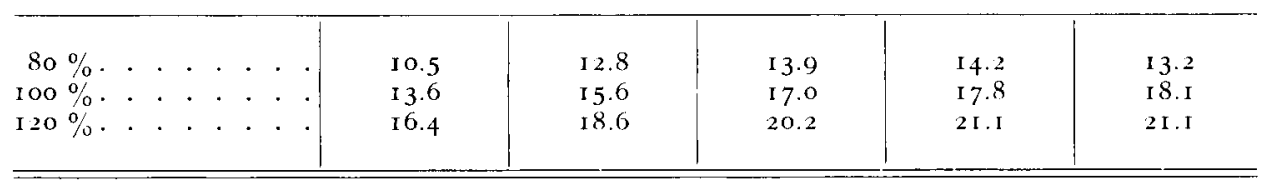

The composition of the experimental diets as well as their digestibility values and energy content were published by WIESEMüLLER et al. (1978) and PoPPE et al. (I979).

\section{Results}

\section{I. - Castrated males (trial I)}

The daily weight gains and energy expenditure mainly depended on the energy intake. Up to Ioo kg liveweight both low and high levels of amino acid supplies produced the same fattening results as a standard amino acid supply. 
TABLE 2

Daily gain and feed conversion ratio as related to energy and lysine intakes

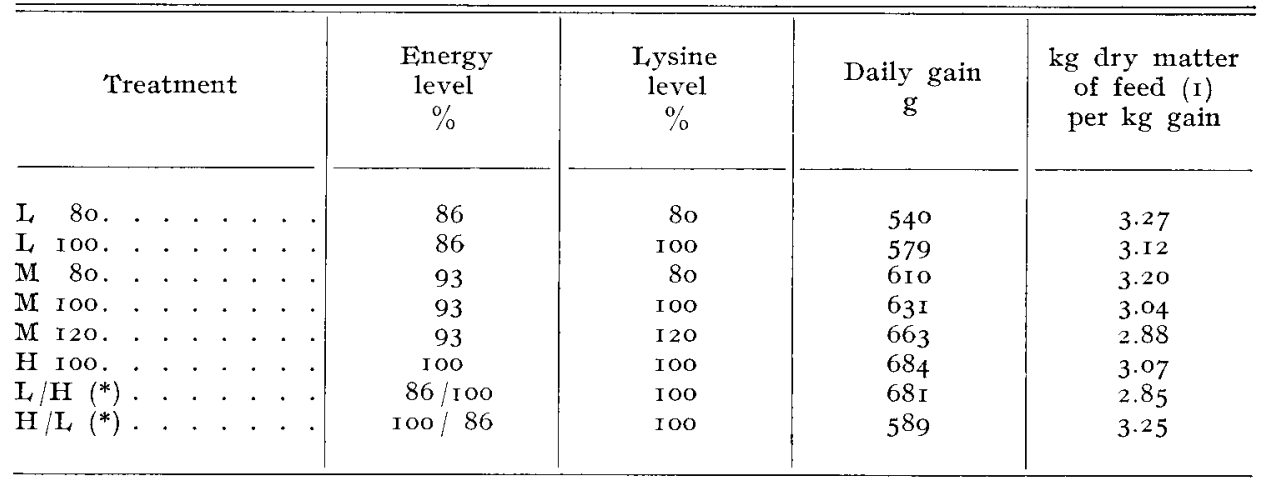

(*) Change on the 39 ih day of the experiment.

(1) I $\mathrm{kg}$ dry matter of feed $=2727 \mathrm{kcal}$ NEFs, i.e. approximately 4.04 Meal D.F.

Within the Ioo to $120 \mathrm{~kg}$ liveweight range, the animals fed higher levels of protein were slightly superior. As to energy expenditure, the animals subjected to restricted feeding up to $70 \mathrm{~kg}$ liveweight and then fed full rations ingested $2.85 \mathrm{~kg}$ feed dry matter per $\mathrm{kg}$ gain and were significantly better than those fed intensively at the beginning of the experiment and restricted beyond $70 \mathrm{~kg}$ liveweight $(3.25 \mathrm{~kg}$ DM per $\mathrm{kg}$ gain), and better than those receiving high levels of energy all the time $(3.07 \mathrm{~kg}$ DM per $\mathrm{kg}$ gain). Using all the gain data within 40 to $120 \mathrm{~kg}$ live weight range, a close linear relationship was established between the daily live weight gain (Y, g $/ \mathrm{kg}^{0.75}$ ) and the daily energy consumption (X, F.U. $/ \mathrm{kg}^{0.75}$ ) according to the equation : $\mathrm{Y}=(-21.06+0.7935) \times\left(\mathrm{R}=0.960, s_{\mathrm{b}}=0.0315\right)$. A total of I26 F.U.* or approximately $0.65 \mathrm{Mcal}$ D.F. was needed for every Ioo g extra live weight gain.

In order to determine the effects of these levels on the composition of gain, the animals from all treatments were slaughtered and analysed when reaching live weights of $40,70,95$ and $120 \mathrm{~kg}$. The growth intensities of the animals expressed as daily protein, water and fat gains on four treatments are shown in figure I.

The daily live weight gain shown by the upper curve remained almost constant throughout the fattening period in pigs with moderate and low energy intakes. The growth intensity exhibited by the pigs on the high energy level (= Ioo) gradually decreased during the fattening period. The daily protein gain of animals on the levels "Middle-IOo" and "Middle-I20" remained almost constant at $85 \mathrm{~g}$ throughout the fattening period. A11 other levels resulted in a reduced protein deposition with increasing live weight from 70 to $95 \mathrm{~kg}$. The greater the gain performance before this range was reached, the more pronounced was this effect. For example, the high energy level ioo increased the daily protein depo-

* I F.U. (feed unit) $=3.5 \mathrm{kcal}$ NFFs, i.e. approximately 5.I $8 \mathrm{kcal}$ D.F. for the experimental diets. 

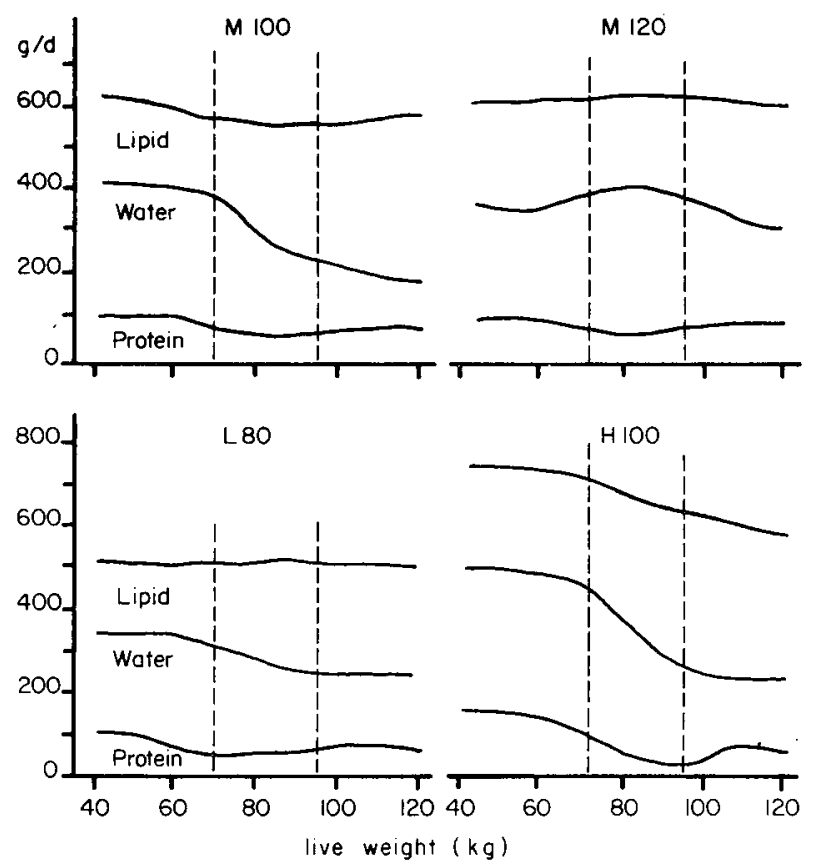

FIG. I. - The composition of daily live weight gain of pigs in relation to energy and lysine intakes.

sition to $133 \mathrm{~g}$ during the initial development period, i.e. by a factor of I.5. As the live weight continued to increase protein deposition was obviously influenced by development at an earlier age and the initial high deposition rate was followed by a negative compensatory effect. The daily fat gain was dependent on the energy intake. The average values for the whole fattening period were $260 \mathrm{~g} / \mathrm{day}$ for the Low energy level, $290 \mathrm{~g} / \mathrm{day}$ for the Medium level, and $360 \mathrm{~g} /$ day for the High level.

Finally, the levels had a decisive effect on the daily water retention of the animals. The results obtained with the M I 20 level showed that muscle growth was connected with water deposition.

The protein contents of animals, all slaughtered at I20 $\mathrm{kg}$ live weight, with

TABLE 3

Comparison of protein content of the whole body with the content of lean cuts (I $20 \mathrm{~kg}$ live weight)

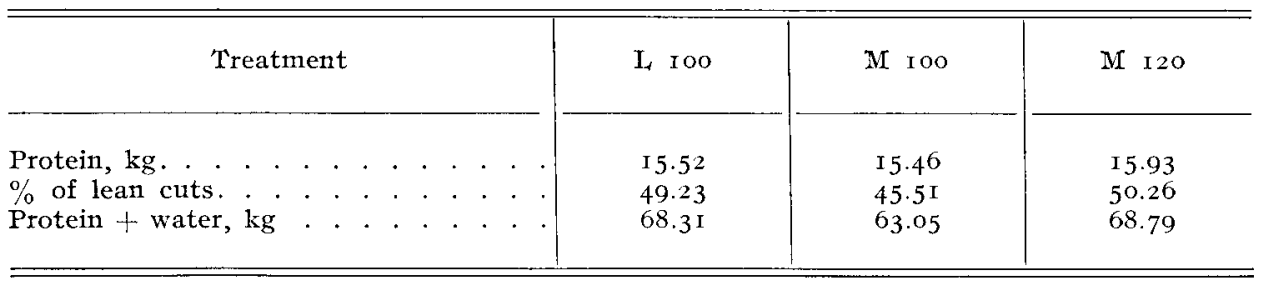


the proportion of lean cuts obtained with threetreatments are compared in table 3 . The latter produced no differences in the protein content, but the animals fed on M roo had 5 p. Ioo less lean cuts per half-carcass than those receiving the other two treatments. This difference could also be shown when the protein and water contents were added together and compared instead of protein alone. The poorest performance exhibited by the animals fed M Ioo and slaughtered at I $20 \mathrm{~kg}$ live weight compared with the animals fed I, Ioo and M I20 can be related to the lower water retention and greater fat deposition during fattening from 95 to $120 \mathrm{~kg}$ live weight.

If the gain is plotted versus time (fig. 2) it is clear how the time taken to reach the final fattening weight of $120 \mathrm{~kg}$ can be used to maximise protein production.

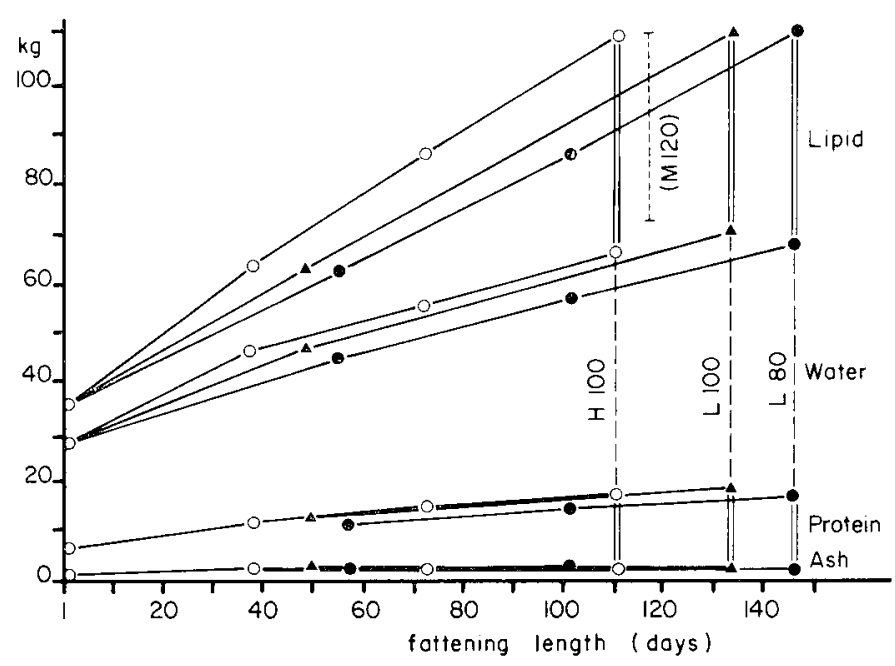

FIG. 2. - Body composition changes during the fattening period. $\mathrm{OH}$ ioo. a L ioo. $\mathrm{L}$ 80

The amounts of energy and amino acids supplied to the animals subjected to treatment MI $\mathrm{I} 20$ fully expressed the protein deposition capacity of the animals while producing a minimum of fat.

This graph shows clearly that protein and fat are produced simultaneously during growth. Although it is possible, by reducing energy intake as in the $\mathrm{L}$, Ioo treatment, to reduce daily fat deposition and thus produce pigs with carcases containing the same amounts of protein and fat as those grown to the full expression of their protein deposition ability, this can be done only at the expense of longer fattering periods and higher energy costs.

The capacity or potential for protein deposition is defined as the genetically programmed ability to deposit protein while reaching a given final weight during the shortest possible fattening period and with a minimum fat deposition. The method chosen to show the results gives a good illustration of the negative effects of protein-deficient diets. The shortest fattening period required to reach a defined final weight depends largely on the genetic constitution of the animal. 


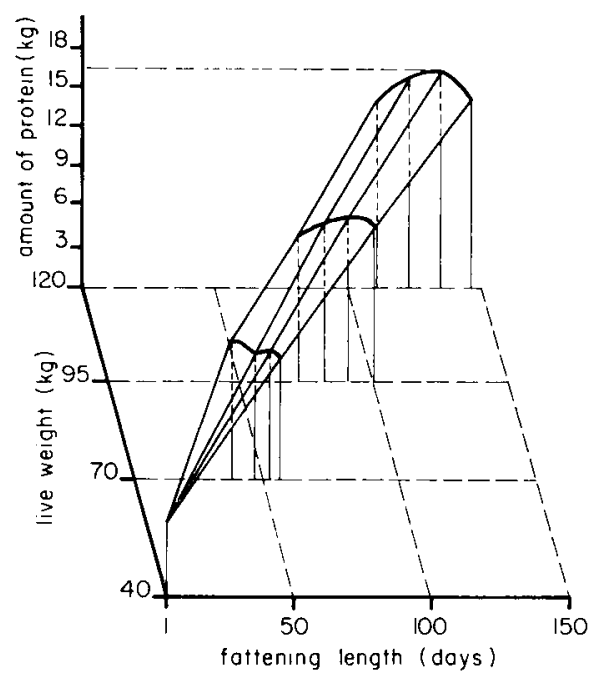

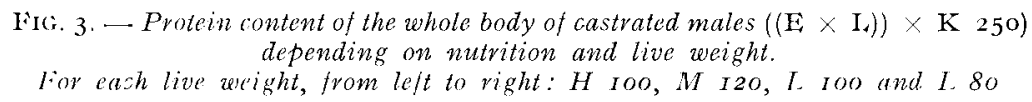

In the GIOR, pigs for slaughter should have a live weight of $\mathrm{I} 20 \mathrm{~kg}$. For this live weight, the protein retention potential of the genotype tested ((Landrace $\times$ Edelschwein) $\times \mathrm{K} 250$ ) allowed a final amount of $\mathrm{I} 6 \mathrm{~kg}$ protein in the body (fig. 3).

This maximum protein content of $16 \mathrm{~kg}$ was achieved by the animals on treatment L 100 and those fed more intensively on $\mathrm{M} \mathrm{I} z \mathrm{O}$. However, the protein deposition potential must be considered as a gain per unit of time. This potential was fully used by the animals on treatment $\mathrm{M}$ I2O. The forced protein deposition achieved during the first half of the fattening period in animals on $\mathrm{H}$ Ioo made these animals superior at $70 \mathrm{~kg}$ live weight. The subsequent drop in protein deposition accompanied by an increased fat deposition, however, indicated that the protein deposition potential was no longer fully used at $120 \mathrm{~kg}$ live weight.

Since, under practical pig fattening conditions, high-energy diets are provided ad libitum and the reduced performance during the second part of the fattening period is a cause of general concern, any differences induced by changing the energy input levels at a live weight of about $70 \mathrm{~kg}$ would be of interest. For this reason, the $\mathrm{L}-\mathrm{H}$ level in our studies corresponded to the $\mathrm{L}$ roo treatment up to day 39 of the experiment and to $\mathrm{H}_{\mathrm{I}}$ oo thereafter, i.e. the animals were on $\mathrm{L}_{4}$ Ioo level up to day $39(65 \mathrm{~kg}$ live weight), whereafter they were fed on treatment $\mathrm{H}$ roo. The growth intensity and composition of gain of these animals are shown in figure 4 .

The change from a low to a high energy intake level resulted in a substantial increase in the rate of gain first accompanied by an increase in daily fat deposition. However, the situation changed in the course of further growth until the daily protein deposition rate rose to II $5 \mathrm{~g}$ during the fattening period from 95 to $120 \mathrm{~kg}$ live weight. This is also an evidence of the high meat production rate of these arimals even towards the end of the fattening period. The high rates of gain 

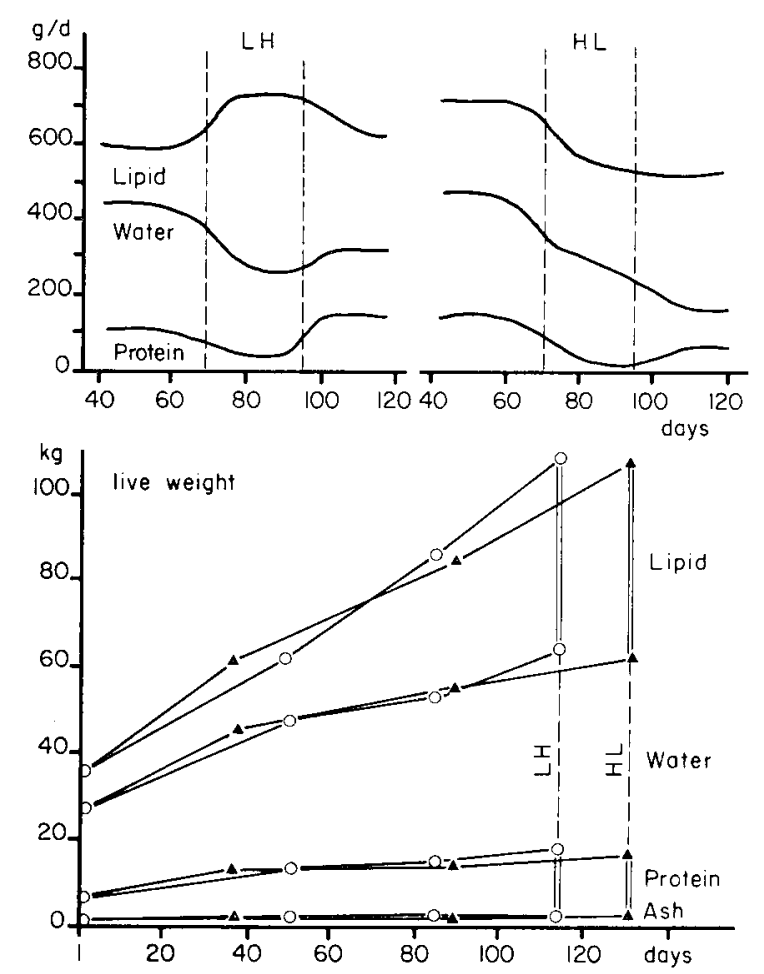

FIG. 4. - Influence of changes in the energy input levels at a live weight of about $65 \mathrm{hg}$ on growth intensity and composition of gain.

LH : Low-High; HL : High-Low. O LH; $\boldsymbol{L}$ - HL.

shortened the second part of the fattening period to such ar extent that these animals had the lowest energy costs.

The lower intake involved in the H-L-programme produced no substantially lower fat deposition, but, due to the reduction in energy intake, the daily protein deposition rate dropped to below the level reached by means of the $\mathrm{H}$ roo treatment alone.

\section{2. - Fattening gilts 'trial 2)}

More recently Goldmann (I978), Poppe et al., (I979) investigated the same problems by using (Fdelschweir $\times$ Landrace) $\times$ F I50 crossbred pigs. Daily gains are shown in table 4 . In addition 5 castrated males i $i_{2}$ each treatment were fattened for comparison.

The weight increase and feed conversion ratio showed a distinct deperdence on the energy level of the ration and were mainly determined by the energy intake. Up to a live weight of $90 \mathrm{~kg}$ a $20 \mathrm{p}$. Ioo lysine over or undersupply in comparison with the recommended level had no influence on the growth intensity of the animals. On the low and medium energy levels there was a tendency for a superiority of the animals which received protein rich feeds between go and 


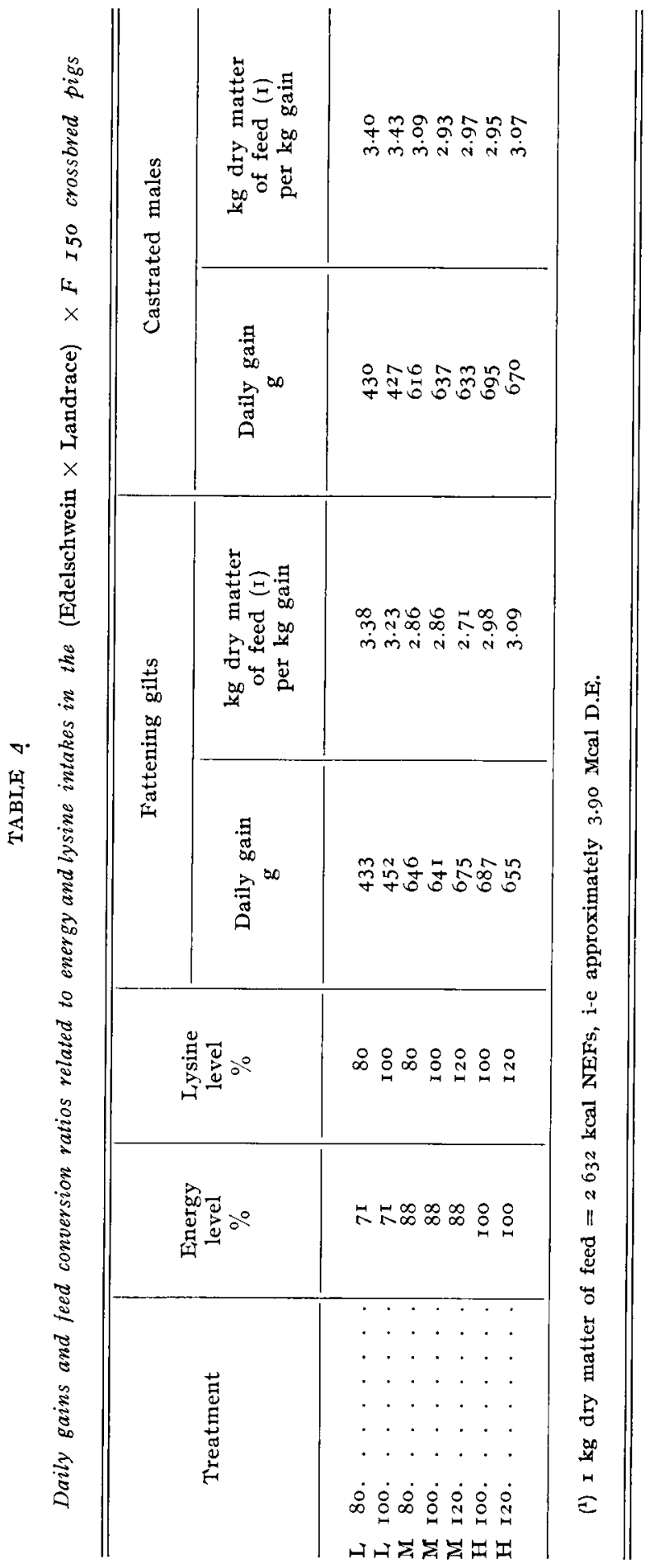


I $20 \mathrm{~kg}$. However, with a high energy level a smaller increase was detected in the last third of the fattening period in connection with the increasing level of lysine. The most suitable result by gilts was obtained with M I20, i.e. a daily increase of $675 \mathrm{~g}$ and a feed conversion ratio of $2.7 \mathrm{I} \mathrm{kg}$ dry matter of feed per $\mathrm{kg}$ weight gain.

With all gain data of the 40 to $\mathrm{I} 20 \mathrm{~kg}$ live weight range, a close linear relationship was established between daily live weight gain $\left(\mathrm{Y}, \mathrm{g} / \mathrm{kg}^{0.75}\right)$ and daily energy consumption (X, F.U. $\left./ \mathrm{kg}^{0.75}\right)$, according to the equation : $\mathrm{Y}=(-\mathrm{I} 3.97$ $+0.7037) \times\left(\mathrm{R}=0.836 ; s_{\mathrm{b}}=0.0295\right)$. This and the former equation rere the basis of the energy requirement data in table 7 .

Figure 5 shows the variation in the protein content of gilts.

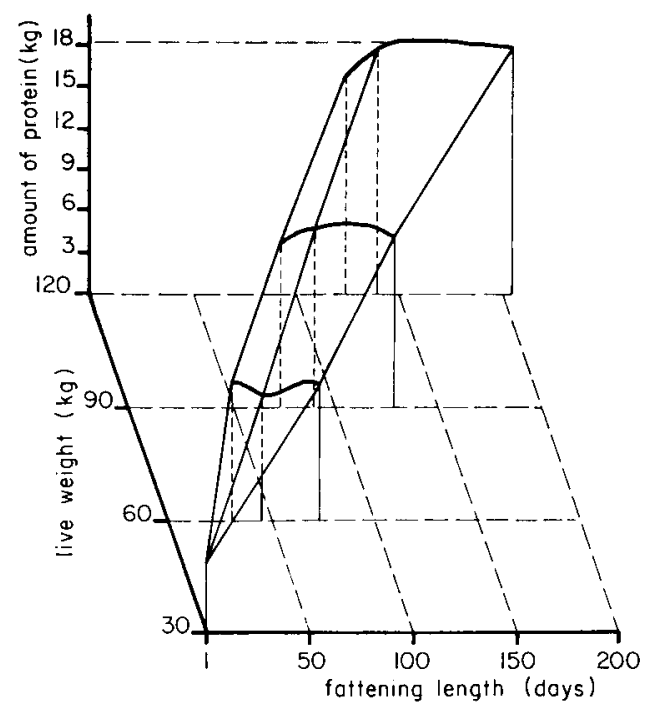

FIG. 5. - The protein content of the whole body of fattening gilts $((E \times L) \times F$ I 50) according to nutrition and live weight.

For each live weight, from left to right: $H$ Ioo + I2O, $M$ Ioo and $L$ Ioo.

Four treatments were compared with the previously described experiment. In this case a protein deposition potential of around $\mathrm{I} 8 \mathrm{~kg}$ at a slaughter weight of $\mathrm{I} 20 \mathrm{~kg}$ was also achieved by using a moderate level of energy intake accompanied by an adequate level of lysine intake. The animals fed on the Low Ioo treatment with an extremely low energy content reached exactly the same satisfactory carcass characteristics but considerably later with a mean daily gain of $430 \mathrm{~g}$.

It is interesting to note that a high energy intake during the first part of the fattening period also greatly stimulated protein deposition in this case. As in the previous experiment, the daily protein gain was I30 g. However, protein deposition also decreased as fattening proceeded in the case of this meat-producing crossbred pigs, and these losses could not be compensated for by the greater amino acid intake of the animals on the $\mathrm{H}$ I20 treatment. 


\section{Discussion and Gonclusion}

To optimize energy and lysine allowances for a given slaughter weight, there is a need to adjust the energy level and profile to the final fattening weight. This is of great importance for producing heavy pigs as compared to lighter ones. It can be concluded that very high energy intakes during the first part of the fattening period are advisable if the animals are to be slaughtered at a live weight of $90 \mathrm{~kg}$. If the final fattening weight is to be $120 \mathrm{~kg}$, a too intensive intake during the period up to a live weight of about $60 \mathrm{~kg}$ appears to be unfavourable. The reduced protein deposition observed during the second part of the fattening period appears to result from an insufficient expression of the protein deposition ability of the animal. In the case of crossbred pigs, with a high muscle development, any reduction in the energy intake must be prevented during the second part of the fattening period. Therefore with this type of pigs, the energy intake should be increased during this period, as shown by HENRY (I979).

Now we have to derive the most favourable Lysine/energy ratio since this amino acid was the most limiting in our diets. Pigs on treatment $L$ Ioo and $M$ I 20 reached the highest protein contents at a final weight of $120 \mathrm{~kg}$. The better results obtained with these treatments justifies the assumption that, in comparison to the energy intake of the pigs on Mroo and Hroo, lysine intake was not quite sufficient to allow maximum utilisation of the protein deposition potential at live weights beyond $70 \mathrm{~kg}$.

At lower weights, reduced lysine intake was compensated for by a greater utilisation, particularly among the animals on the High roo treatment (table 5). The rate of lysine utilisation was almost $67 \mathrm{p}$. Ioo in the case of these anima's. For the whole fattening period, in animals on treatment $M$ Ioo it was $36 \mathrm{p}$. Ioo, i-e roughly the same as previously found.

On the basis of a constant lysine requirement of $2.0 \mathrm{~g}$ lysine/Mcal digestible energy (table 6), the lysine intake during fattening from 40 to $70 \mathrm{~kg}$ is rather smaller than the levels provided in treatment Lioo and Mioo. However, due to the high rate of 1ysine utilisation, the lower level of lysine intake had no negative effect on protein deposition between these weight limits. This fact must be

TABLE 5

Rate of lysine utilisation for growth (\%)

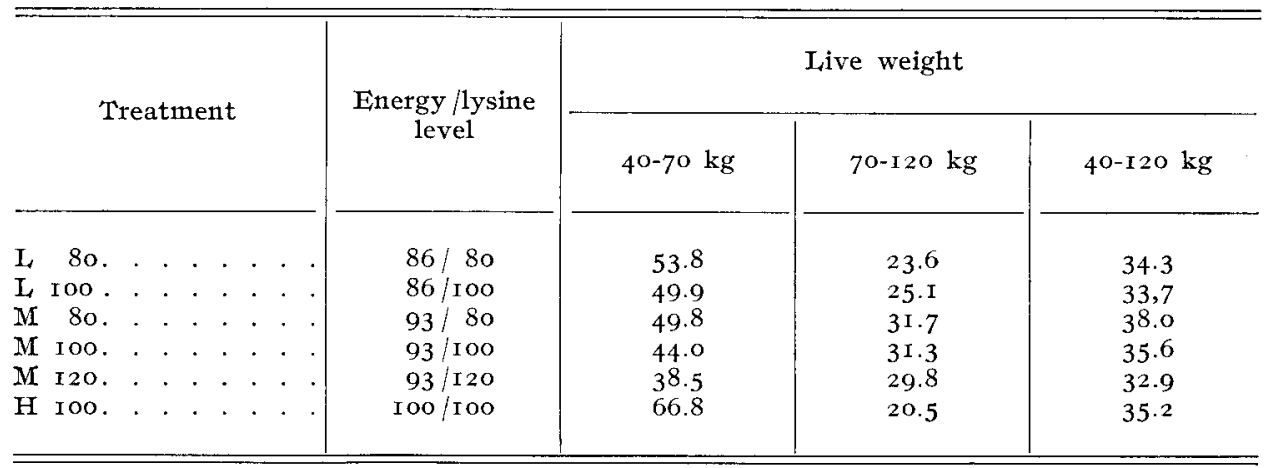


TABLE 6

Lysine (energy ratios in the experimental diets (trial I) Amounts in g/Mcal D.E.

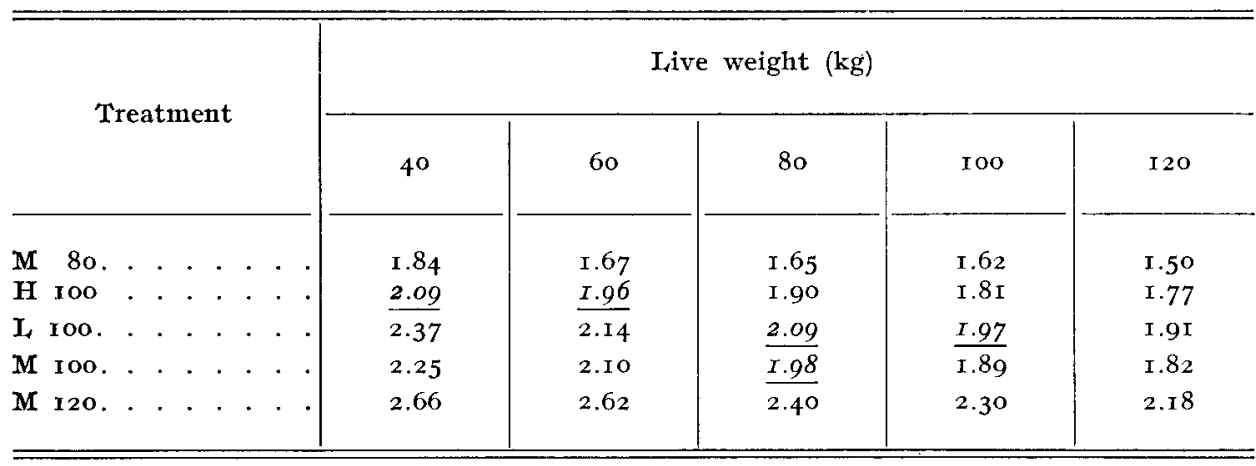

TABLE 7

Energy and lysine requirements of growing-fattening pigs as related to growth performance

\begin{tabular}{|c|c|c|c|c|c|c|c|c|c|c|c|}
\hline \multirow{2}{*}{\multicolumn{6}{|c|}{ Daily gain (g) }} & \multicolumn{2}{|c|}{500} & \multicolumn{2}{|c|}{600} & \multicolumn{2}{|c|}{700} \\
\hline & & & & & & $\mathrm{CM}$ & $\mathbf{F}$ & $\mathrm{CM}$ & $F$ & $\mathrm{CM}$ & $\mathrm{F}$ \\
\hline Live & we & $g 1$ & $t$ & $(\mathrm{~kg})$ & & & $\mathrm{Da}$ & ergy $n$ & $5(\mathrm{Mcc}$ & & \\
\hline 40 . & . & & & $\cdot \cdot$ & $\cdot 1$ & $5 \cdot 45$ & $5 \cdot 3 \mathrm{I}$ & 6.10 & 6.05 & 6.75 & 6.75 \\
\hline 50. & . & & & $\cdot \cdot$ &. & 5.85 & 5.62 & $6.5^{\circ}$ & 6.35 & 7.15 & 7.09 \\
\hline 60. & . & & . & . . & . & 6.23 & 5.90 & 6.88 & 6.64 & $7 \cdot 53$ & $7 \cdot 37$ \\
\hline 70 & . & & . & . . &. & 6.59 & 6.17 & 7.24 & $6.9^{\circ}$ & 7.89 & 7.64 \\
\hline 80 . & . & & . & $\cdot$. & 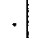 & 6.94 & 6.43 & 7.59 & 7.17 & 8.25 & 7.90 \\
\hline 90. & - & & 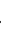 & . . & . & $7 \cdot 28$ & 6.69 & 7.94 & $7 \cdot 4^{2}$ & 8.59 & 8.16 \\
\hline xoo. & . & & & 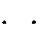 & $\cdot$ & $7.6 \mathrm{I}$ & 6,93 & 8.26 & 7.67 & $8.9 \mathrm{I}$ & $8.4^{\circ}$ \\
\hline IIO. & . & & " & 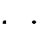 & t & 7.94 & 7.17 & 8.59 & $7 \cdot 9 \mathrm{I}$ & 9.24 & 8.65 \\
\hline $\mathbf{I} 20$. & . & & & 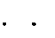 & 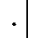 & 8.25 & $7 \cdot 4^{\mathrm{I}}$ & 8.90 & 8.14 & 9.55 & 8.88 \\
\hline
\end{tabular}

Daily lysine needs (g)

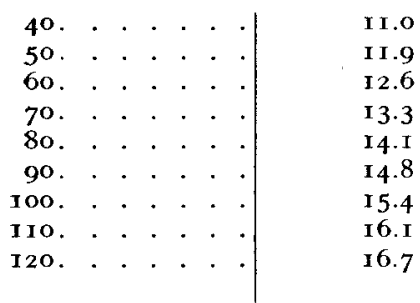

dations in GDR

$\mathbf{C M}=$ Castrated males, $\mathbf{F}=$ Females. 
checked during further studies. Full utilisation of the protein deposition potential until the end of the fattening period is ensured by the intake of $2.0 \mathrm{~g}$ lysine /Mcal D.E. corresponding to the value recommended by HENRY, PION and RERAT (I976) for fattening pigs between 50 and roo $\mathrm{kg}$ live weight. For fattening gilts with smaller needs in the energy intake the lysine/energy ratio could be $2.2 \mathrm{~g} / \mathrm{Mcal}$ D.E., but for a common fattening of castrated males and gilts until $120 \mathrm{~kg}$ the ratio of $2.0 \mathrm{~g}$ lysine/Mcal D.E. is sufficient.

Taking into account the lysine requirement of $2.0 \mathrm{~g} / \mathrm{Mcal}$ D.E. and the energy requirement of growing pigs, the variation with live weight and average daily gain in the daily energy and lysine requirement is shown in table 7 .

The current recommendations applied in GDR were determined by using pigs with daily gains of about $700 \mathrm{~g}$ (POPPE and WIESEMÜL,,$E R$, I968; WIESEM ÜL,ER, POPPE and SIEG, I974). These recommendations are in a good agreement with those presented here for daily gains up to $700 \mathrm{~g}$ and up to $90 \mathrm{~kg}$ live weight. On account of a constant high rate of protein deposition provided by modern genotypes, the lysine/energy ratio selected here should be maintained up to a final weight of $120 \mathrm{~kg}$. This results in a slightly higher lysine requirement than currently recommended.

Digestibility values are not included in this table. The lysine digestibility of the mixed feed used in our experiments, tested under standardized conditions to secure the amino acid requirements, was $9 \mathrm{I}$ p. Ioo. Our nitrogen balance experiments performed to determine the amino acid requirement were also based on a lysine digestibility of $90 \mathrm{p}$. Ioo and this is why the present requirement values are in good agreement with the recommended ones. However, the protein and amino acid digestibility of the feeds currently used in agricultural practice is far below $90 \mathrm{p}$. I 00 in many instances. For this reason, the figures regarding both requirements and feed contents should refer to the digestible fraction in the case of amino acids. On account of the apparent lysine digestibility of $9 \mathrm{I} p$. Ioo determined in our experiments, the calculated digestible lysine requirement for pigs of a modern genotype is $\mathrm{r} .8 \mathrm{~g} / \mathrm{Mcal} \mathrm{D}$.E. Table 8 shows the daily requirements

TABLE 8

Proposals for the supply of digestible lysine to fattening pigs (g per day)

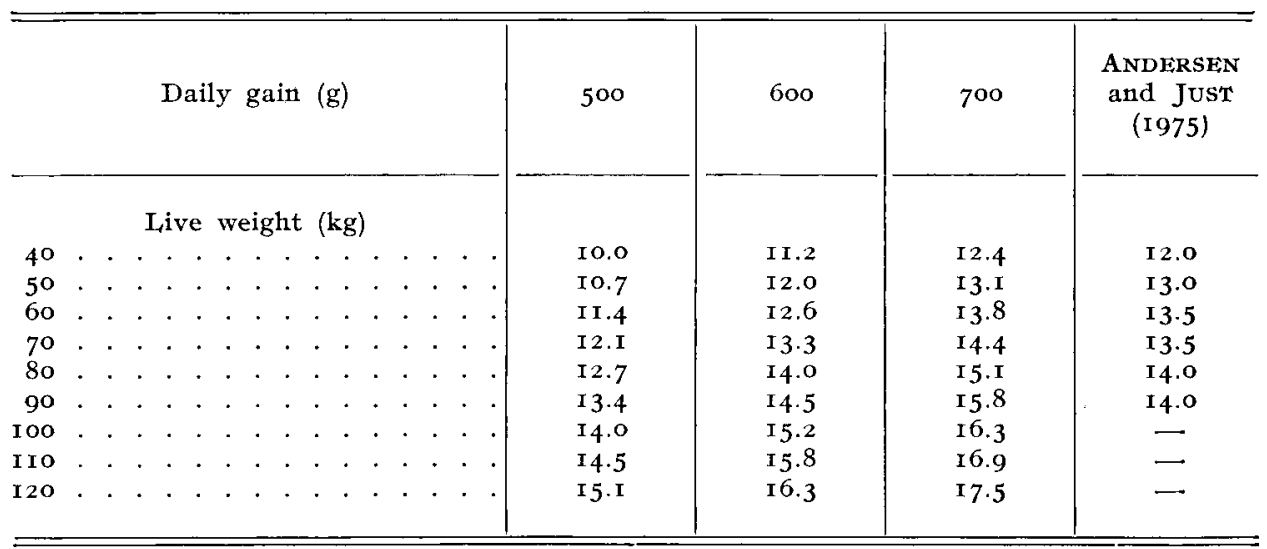


for digestible lysine according to live weight and daily gain. The values are in good agreement with the Danish recommendations (ANDERSEN and JUST, I975).

Accepté pour publication en Juin 1980.

\section{Acknowledgements}

The author wishes to acknowledge Mrs. K. Rérat and Mr. Y. Henry for the correction of the manuscript and translation of the summary into French.

\section{Résumé}

\section{Besoins en acides aminés (lysine) du porc en croissance Méthodes d'approche et recommandations}

La sélection de porcs de type maigre se traduit par un accroissement plus soutenu du dépôt journalier de tissus maigres et, par voie de conséquence, par une augmentation concomitante du besoin journalier de lysine. Il en découle que le rapport lysine/énergie se situe à un niveau relativement constant pendant la durée de l'engraissement entre 35 et $120 \mathrm{~kg}$ du poids vif.

Des caractéristiques de carcasse comparables, c'est-à-dire les mêmes quantités de protéines fixées, à un poids d'abattage donné, peuvent être obtenues à l'aide de programmes alimentaires distincts (niveau énergétique et rapport lysine /énergie). Pour l'acide aminé limitant primaire (lysine), le rapport lysine /énergie se situe à 2,o g/Mcal d'énergie digestible (E.D.), ou I, $8 \mathrm{~g}$ de lysine digestible/Mcal E.D., en prenant en compte la digestibilité de l'acide aminé. Afin d'optimiser les apports recommandés d'énergie et de protéines (lysine) pour un poids d'abattage donné, le niveau et le profil de l'apport énergétique devraient être ajustés au poids final d'abattage. Ceci est très important pour la production de porcs lourds comparativement à ceux abattus à un poids plus faible.

Un niveau très élevé d'apport énergétique dans l'intervalle de poids $35-7^{\circ} \mathrm{kg}$ entraîne une diminution du gain pondéral et du dépôt de protéines à la fin de la période d'engraissement (au delà de $90 \mathrm{~kg}$ de poids vif). Cet effet dépressif ne peut pas être compensé par un haut niveau de complémentation azotée. Un niveau alimentaire trop intensif au cours de la première partie de l'engraissement (plus de $65^{\circ} \mathrm{g}$ de gain $/ \mathrm{j}$ ) aboutit à des résultats défavorables au poids final de $120 \mathrm{~kg}$. La diminution đu dépôt de protéines pendant la deuxième partie de l'engraissement est le reflet d'une expression insuffisante du potentiel de développement musculaire. Ce potentiel est défini par la limite supérieure du dépôt azoté (et par conséquent de la production de tissus maigres) chez un porc à l'engraissement, à un poids final donné, permettant d'atteindre le seuil minimum à la fois pour la durée d'engraissement et le dépôt de gras. Lors de la production de pores lourds, une réduction par l'apport énergétique pendant la deuxième moitié de l'engraissement n'est pas conseillée dans le cas de l'utilisation de pores de type maigre, provenant des croisements modernes. Au contraire, il importe que le niveau de l'apport énergétique soit suffisant durant la seconde partie de l'engraissement pour ne pas limiter le dépôt de tissus maigres.

\section{References}

ANDERSEN E., JUST A., 1975. Tabeller over fodermidlers sammensaetning m.m. Kvaeg-Svin; Det kgl. Danske Landhusholdningsselskab, København.

GoLDMANN Sylvia, I978. Untersuchungen zum Aminosäurenbedart wachsender weiblicher Mastschweine. Thesis, W.-Pieck-Universität Rostock.

Henky Y., PION R., RERAT A., 1976. Protein supply for pigs and possibilities of reducing protein feeding standards. World Rev. Anim. Prod. I2, $\mathrm{N}^{\mathrm{O}}{ }_{\mathrm{I}}: 9-32$.

HENRY Y., 1979. Feed Intake Regulation for growth in the Pig; Wiss. Z. W.-P.-Univ. Rostock 28, I $29-\mathrm{I} 35$. 
JANCKER H., POPPE S., I975. Untersuchungen zum Lysinbedarf wachsender Mastschweine (männl. Kastrate) im Lebendmasseabschnitt von 50 bis II $5 \mathrm{~kg}$. Jahrb. Tierernährung u. Fütterung. 9, I83-192.

POPPE S., WIESEMÜLILER W., 1968 Untersuchungen über den Aminosäurenbedarf wachsender Schweine. Arch. Tievernähr. 18, 392-4 I6.

Poppe S., Goldmann Sylvia, HaCkL W., WIEsem t́llek W., 1979. Untersuchungen zum leistungsabhängigen Lysinbedarf von Mastsauen. Arch. Tievernähr. 29, 349-358; 413-4I8.

WIESEMúliter W., POPPE S., 1969. Die Bewertung der Proteine durcli die Bestimmung der N-Bilanz. Arch. Tievernähr. 19, I33-147.

WIESEM ÜLLER W, POPPE S., I 969 . Zum biologischen Wert einiger Futterproteine beim Schwein. Arch. Tievernähr. 19, I57-I69, I 7I-I 85, 273-279.

WIESEM ÜLLER W., POPPE S., SIEG G., I974. Untersuchungen zum Aminosäurenbedarf von Mastschweinen (Börge). Arch. Tievernähr. 24, 397-406, 407-4r9, 453-463, 465-477.

WIESEM ÜLLER W., POPPE S., HACKL W., 1978. Untersuchungen zum leistungsabhangigen Lysinbedarf von Mastschweinen. Arch. Tievernähr. 28, 31-43, I65-I 7 I.

WIESEM ÜLEER W., OTTO E., POPPE S., BEFM R., HACKL, W., I978. Untersuchungen zum leistungsabhängigen Lysinbedarf von Mastschweinen. Arch. Tievernähr. 28, 305-316, 479-490. 